\title{
International enterprise in Poland - benefits and risks
}

Beata Glinkowska, Ph.D.

University of Lodz,

Department of Management

Prof. Bogusław Kaczmarek

University of Lodz,

Department of Management

\section{Introduction}

Nowadays any resources are able to flow freer between different countries, which is caused by the market globalization and liberalization. The number of possibilities of enterprises is constantly increasing. Various organizational and legal forms of companies, including those multinational, are under development. The economical role and rank of those companies grows in each country.

The focus on the nature and functioning of international businesses in Poland is presented in this article. Was taken into account mainly micro-enterprises. A quantitative analysis of number of the foreign direct investments (FDI) in Poland in 2014 and comparison with the data from ten years ago was prepared by the authors. An analysis of selected literature positions and documents was made to answer the question about the type of benefits and risks, which appear in investments executed by multinational enterprises. Identify the benefits and risks of foreign direct investment, have become a goal this study. 


\section{The essence and definitions of international enterprise}

International enterprises are usually understood as multinational and global according to R.W. Gryffin (Griffin 1996, 168). They can be located in one or many foreign markets. Their products can be sold in few countries or among the whole world (e.g. Coca-Cola and McDonald's). Except of the term "international enterprise" following terms were mentioned by J. Czupiał (2011, p. 13; Zaorska 1998, p. 57; Liberska 2002, p. 39):

- multinational,

- transnational,

- global,

- supranational.

International enterprise is an enterprise, which performs its management functions behind the borders of the country, as defined by J. Lichtarski (2001, p. 393). Mentioned functions can be performed due to the resources integration and coordination (taking into account the variability of complex international environment influences and predicting the effects of this interactions) (Lichtarski 2001, p. 394). A search for competitive advantage is a basic driving force to expand foreign markets for many companies. The ability to compete constitutes a deciding factor whether the company can enter a foreign market. Willing of the company to internationalize its activities is correlated to its export, as claimed by Porter (1990, pp. 545-546). According to J. Rymarczyk (2004, p. 24) the intensity of internationalization in the enterprise can be indicated by the following factors:

- number of expanded markets abroad,

- participation of company's value abroad in general property,

- share of foreign assets in the total book value of fixed assets,

- share of abroad turnover in a company's total turnover,

- share of abroad profits in total company's profit,

- organizational and organizational-legal forms committed abroad,

- size of foreign direct investment (FDI),

- shares in foreign markets,

- number of employees abroad in total number of employees in the company.

The qualities of international enterprise are the same as those of a national one, however the strength of the qualities can be different, depending on the company's mobility or expansion. An essential difference lays between national and international environment. An international enterprise is usually very dynamic, very often changes in its: structure, size, culture, management and 
relationships with environment. Changes are related to different conditions existing in the country, where an enterprise is operating (host country).

\section{International enterprises in Poland}

A branch of a business in Poland can be established on the same rules for both: Polish entrepreneur and an entrepreneur who comes from country which is an EU or EFTA member or one who has a residence permit in Poland, even though headquarters of the company are located in a different country (Sudoł 2006, p. 316). A limited liability company, branch, plant and representation are the most popular forms of business led by foreign entrepreneurs. The economic activity of international business in Poland is regulated by the Act of Freedom of Economic Activities from July 2, 2004. Foreign investments in Polish economy are observed more often than Polish entrepreneurs' investments in foreign markets. Internationalization of Polish enterprises is seen as a passive process due to the approach based on not looking for new opportunities, but also avoiding risks, coming from the aggressive competition.

International enterprises invest relatively high assets and perform research in each hosting country, where conditions are favourable and risks are rather low. According to Michalski (Michalski, 2012, p. 564) the main reason for company activities' transfer to another country is lower labour cost, thus the country borders and regulations have secondary meaning. Lack of possibilities to develop can be another reason for the transfer (Duliniec 2004, p. 15). According to A. Bielewska (2006, p.15) "recently almost each successful enterprise considers an option of expanding foreign markets at some point (...)". "Possibility of international flow of assets and goods is a condition for expanding international enterprise (Fonfara 2009, p. 11).

The speed and level of internationalization is mostly influenced by the following factors (Przytuła 2007, pp. 44-46):

- privatization of large state-owned enterprises and creation of capital groups,

- creation and modification of laws favouring Freedom of Action and increasing entrepreneurship level,

- processes of economic liberalization in trade and flow of goods and capital,

- Polish accession to economic, military and political groups (OECD, NATO, EU),

- increase of trust in Poland as a strategic partner.

Polish market is becoming attractive to foreign investors. S. Przytuła (2007, p. 47) lists the following factors of attractiveness of the Polish market:

- relatively low labour costs, 
- prospects for development and economic growth of the Polish economy,

- availability of specialists,

- geographical location,

- legal security.

Political stability, convertibility of currency, regulation of ownership issues, existence of environment protection standards, low taxes, availability of raw materials, ability to acquire land and property are other factors mentioned as attractive (Służyński 1997, p. 222). A number of foreign direct investments (FDI) increases due to mentioned advantages. A "know-how" transfer to Polish enterprises and creation of new relationships are promoted. The largest increase in FDI in Poland was noted in years 2006-2007 (respectively €15.74 billion and $€ 17.24$ billion). In 2008, the number of FDI fell down to $€ 10.09$ billion. However, taking into account the long-term duration, an upward trend of foreign investment in Poland has been observed since 1994 until now. The status of FDI in Poland at the end of 2014 is shown in the figure 1.

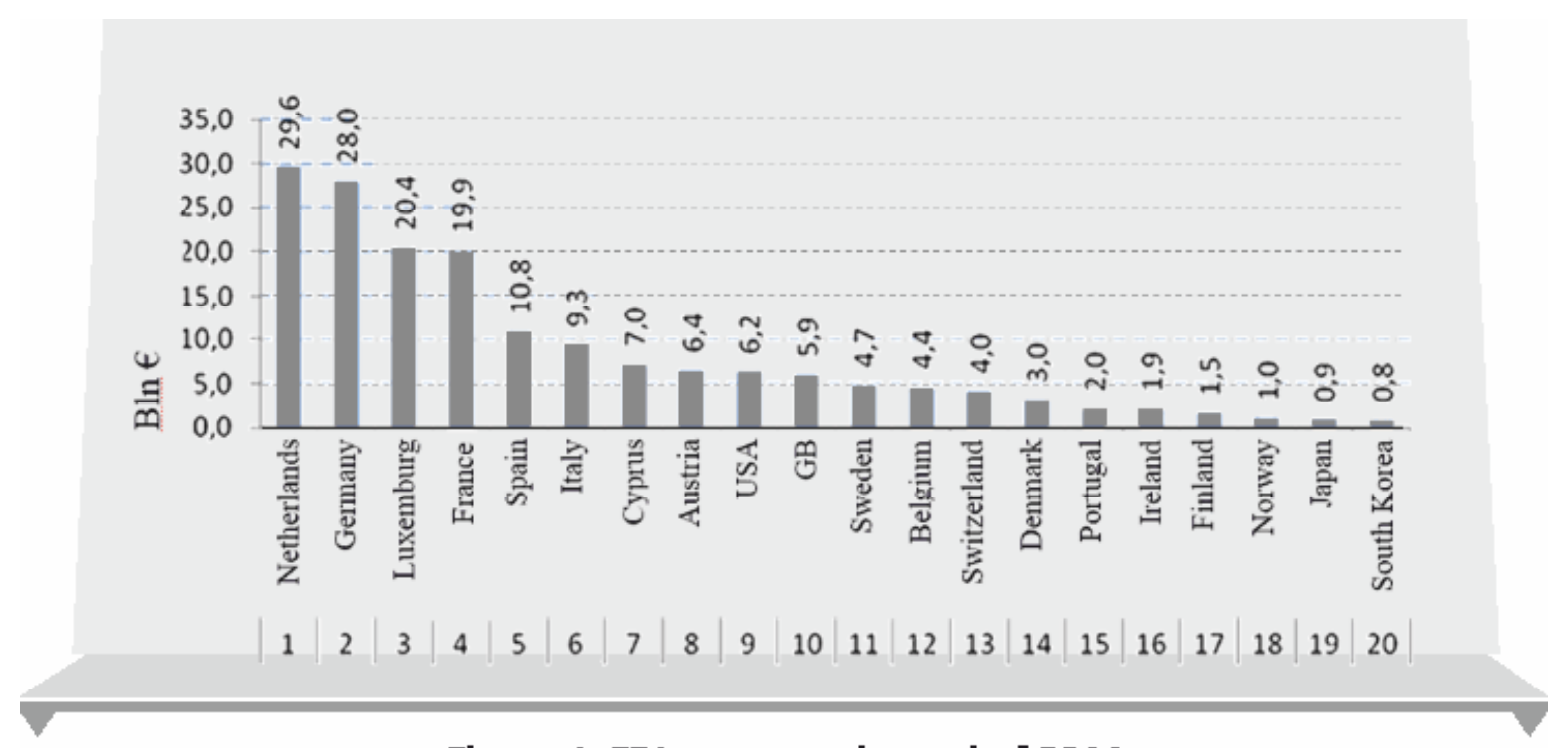

Figure 1. FDI status at the end of 2014

Source: http://www.paiz.gov.pl/polska_w_liczbach/inwestycje_zagraniczne (accesses 31.01.2016)

A conclusion drawn from Figure 1 is that the main FDI input in Poland comes from: Netherlands, (€29.6 bln), Germany (€28.0 bln), Luxemburg (€24.0 bln), France ( $€ 19.9$ bln). Next are Austria, Great Britain, Sweden and Ireland. 
At the end of the list figured are: Norway, Japan and South Korea (€2.7 bln in total).

FDI arriving to Poland are usually: greenfield, privatization, M\&A and joint venture type. The sectors concerned are usually: financial, chemical, automotive, pharmaceutical, telecommunication and multimedia (Przytuła 2007, pp. 44-46).

The participation of FDI in national income was about 3\% in 2008 (http:// finanse.wnp.pl/5-6-proc-udzialu-biz-w-pkb-za-piec-lat,41635_1_0_0.html, accessed 01.02.2016). It is planned to increase it to $25 \%$ till year 2020 . This scenario is captured in a project of acquiring foreign direct investment strategy in years 2014-2020 (https://www.funduszeeuropejskie.2007-2013.gov.pl/Strony/glowna. aspx, accessed 01.02.2016).

According to D. Sadłakowski (2015, pp. 157-168) the participation of FDI in the GDP increases constantly. In 2000 it was $€ 6$ bln and in 2013 already $€ 14$ bln (figure 2).

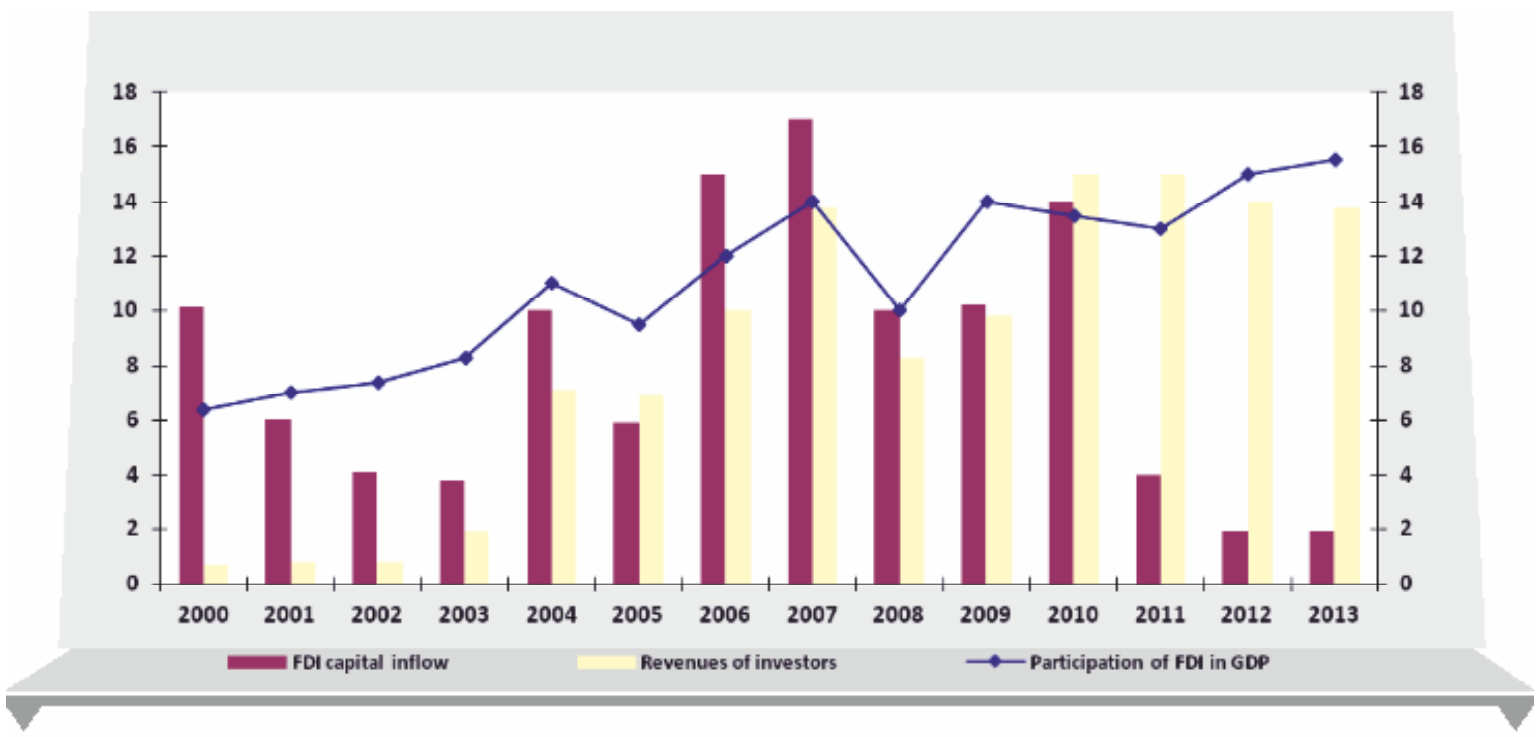

Figure 2. Comparison of FDI capital inflow to a revenue of foreign investors and GDP (in bln $\theta$ )

Source: own study based on (Sadłakowski 2015, pp. 157-168)

Figure 2 shows that the inflow of FDI was very high between years 2000 and 2003. More than $€ 10$ bln inflew to Poland as FDI. The revenue of foreign investors was rather low in mentioned years. For example the revenue of less than $€ 1 \mathrm{bln}$ was noted in year 2000, similar situation was observed in the next 2 years. The 
revenue of foreign investors started to raise form 2003. Also the inflow of capital as FDI started to increase, giving $€ 16$ bln in 2007. The revenue of the investors reached almost $€ 14 \mathrm{bln}$ in the same year.The revenue of investors started to repeatedly exceed the inflow of FDI capital, which is a unique phenomenon in a world scale. For example, FDI capital inflow in 2013 was about $€ 2$ bln and the foreign investors' revenue was $€ 12 \mathrm{bln}$.

Whirpool (USA), Matsuhita Polska Ltd. (Japan), Motorola Polska Ltd. (USA), Metro Group (Germany), Sanden Manufacturing Ltd. (Japan), Statoil Polska (GB), Volvo Group (Sweden), French Chamber of Commerce and Industry (France), BP Polska (GB), Basen Orlen Polyolefins Ltd. (Poland, Finland), Lafarge Cement Polska SA (France) are the biggest and most famous international enterprises in Poland (Przytuła 2007, pp. 48-49). Directions of FDI inflow in years 2008-2013 are summarized in tab. 1.

Table 1. Compilation of FDI inflow sources in Poland in years 2008-2013 (countries)

\begin{tabular}{c|c|c|c|c|c|c}
\hline $\mathrm{N}^{\circ}$ & 2008 & 2009 & 2010 & 2011 & 2012 & 2013 \\
\hline 1. & Germany & Germany & Jersey & Luxemburg & Germany & W. Brytania \\
\hline 2. & Netherlands & France & Germany & Spain & France & Germany \\
\hline 3. & Luxemburg & Luxemburg & Luxemburg & Germany & G. Britain & Switzerland \\
\hline & Sweden & USA & Cyprus & Sweden & Austria & Austria \\
\hline 5. & France & Sweden & Sweden & France & Cyprus & Netherlands \\
\hline 6. & Cyprus & Austria & France & Cyprus & Switzerland & Ireland \\
\hline 7. & Austria & Netherlands & Italy & Greece & Spain & Norwey \\
\hline 8. & Iceland & Italy & Spain & Belgium & Belgium & USA \\
\hline 9. & USA & Spain & G. Britain & G. Britain & Italy & France \\
\hline 10. & G. Britain & Denmark & Ireland & Curacao & Ireland & Spain \\
\hline
\end{tabular}

Source: prepared on the basis of: FDI in Poland in 2013, Department of Strategy and Analyses, Ministry of Economy, Warsaw 2015, p.15

A relatively high and constant inflow of FDI from Germany in years 2008-2013 can be observed. However, the FDI coming from Sweden and Luxemburg has decreased, despite they had high positions in years 2008-2009. The position of 
Great Britain strengthens in creation of FDI in Poland. The GB took 1st place in 2013, followed by Germany, Switzerland, Austria, Netherlands, Ireland and Norway. The rank of USA and Spain is still decreasing in this field.

Foreign direct investments in Poland bring many profits but also risks, as it can be found in many literature positions form this topic.

\section{Benefits and risks generated by creation and development of international enterprises in Poland}

An internationalization process of enterprise is complex and stepwise. Low knowledge about the aspects of a foreign market (its culture, law, region conditioning, demands, mode, way of cooperation and settlements) causes barriers, difficulties, however also possibilities, chances and benefits as noticed by K. Fonfara (2009). Changes in company's environment and its surroundings have a great influence on the activities of a company. International circle consists of environments from various countries, with different economy systems, culture, law and political systems and different levels of economic and technic development (Czupiał 2011). The currency and its stability also differs in those countries. Many international enterprises make decision to expand the activities abroad, despite mentioned above risks and difficulties. Those decisions are driven by potential benefits listed below:

- profits increase through expansion of other markets and growth,

- benefits coming from localization of the company, where the costs are lower,

- effect of experience and learning (G. S. Yip 2004, p. 84),

- use of know-how.

Table 2 Influence of functioning of international company on the host country

\begin{tabular}{l|l}
\hline Benefits & Risks \\
\hline - Improvement of capital and technology & $\begin{array}{l}\text { - Risk of elimination weaker companies from the } \\
\text { market }\end{array}$ \\
- Revival of the region and local enterprises & $\begin{array}{l}\text { Dependency of economy and country budget on } \\
\text { foreign capital }\end{array}$ \\
- strong stimulus for the local companies & $-\begin{array}{l}\text { Introduction of contradictory interests between } \\
\text { home and international enterprises }\end{array}$ \\
- Motivation of local company for better & $-\begin{array}{l}\text { Negative impact on the balance of payments of } \\
\text { the host country } \\
\text { - Develivity }\end{array}$ \\
areas & $-\begin{array}{l}\text { Technological domination over the local one } \\
\text { - Inflow of know-how and innovations }\end{array}$ \\
- Increase of locals' employment and career & $\begin{array}{l}\text { Threat to the security and sovereignty of the } \\
\text { country }\end{array}$
\end{tabular}


- Chance to compensate the country's balance of payments related to supplementation of the deficit of capital and investments in the economy

- Development and modernization of "backwarded" business sectors

- Creation on new budget income sources

- Improvement of products' quality due to the competition

- Improvement of availability of some goods and services

- Weaker countries gradually involved to a global economy system

- Improvement of work organization, knowledge transfer and employees' qualifications

- Improvement of relationship between countries
Environment contamination, caused by so called "dirty manufacturing"

Possibility of eradication of local companies and increase of unemployment

Possibility of repurchase a local company in order of its liquidation

- Possibility of overtaking control on market and business sectors

Avoiding of paying taxes

Possible disturbances in socio-cultural area and decay of cultural identity of a host country

Transfer of benefits out of the host country

Source: own description prepared on the basis of Jarczewska-Romaniuk 2004, pp. 161-202

The benefits and risks concern an international enterprise as well as a host country for example small, local enterprises of a host country can be placed in risk. International companies usually propose better offers, more experience and higher mobility. On the other hand, they are a chance for regional unemployment decrease, increase of employees' qualifications by transfer of skills or a chance for development of the region, by development of its infrastructure and industrial buildings, which at the end can lead to equalization of development level in different regions. Excessive expansion of inflowing FDI by multinational companies to a specific country may threaten the economic interests of a sovereign state by entering into an area of strategic national industry branches (Grabowski 1998, p. 110).

Usually many benefits come to the host country from FDI, the number of liberalized regulations in Poland to simplify the functioning of international companies can testify that, however not in all countries this liberalization is present, which inclines their government to think. Proper and well analysed legislations are needed, to avoid any abuses, especially in the area of potential exploitation of workers or avoiding the deepening economic disparities between people.

The influence of functioning of international company on the host country has been compared in Table (table 2), elaborated by A. Jarczewska-Romaniuk. 
The expansion of host country market by international companies has various influence. The compilation above shows that this influence can be both: positive and negative. One of most important positive aspects in the functioning of international company in Poland is an improvement of capital and technology inflow. The most dangerous risk seems to be the possibility of elimination native, local entrepreneurship.

\section{Conclusions}

The analysis of benefits and risks with the existence and the inflow of foreign direct investment presented above gives a reason to think and act in governments of many countries especially that the FDI in Poland increases. The inflow of FDI brings many possibilities of benefits and risks. Nowadays native enterprises are offered with governmental help and special benefits, which are aimed to help with entering foreign markets, but also to lower the effects of FDI. Governmental programmes are various, however very often material resources transfer is performed, with a special focus on financial support, immaterial support relays on knowledge transfer. A support programme of enterprises' internationalization can be performed due to those actions, the aim is to improve an international competitiveness of local enterprises and along with that: an increase of national trade balance (Jarczewska-Romaniuk, 2004, p. 82). To the basic benefits of FDI is the development of regions, but it can to threaten the elimination of native of weaker companies.

\section{Summary}

\section{Benefits and risks of international enterprise in Poland}

The article presents chosen issues of inflow of FDI to Poland. The essence and definition of international enterprise is explained as well as the FDI number in Poland in 2014. An increase trend of FDI in Poland is presented the basis of statistical data. An influence of FDI on Polish GDP in years 2000-2013 was analysed. The directions of FDI inflow in Poland in years 2008-2013 are compared. The focus was on benefits and risks related to the presence of foreign enterprises in Poland, allowing for achievement of the objective of this study.

Key words: foreign direct investment, FDI, international enterprise, home market, host market, internationalization. 


\section{Streszczenie}

Przedsiębiorstwo międzynarodowe w Polsce - korzyści i zagrożenia W artykule przedstawiono stan ilościowy związany z napływem do Polski bezpośrednich inwestycji zagranicznych. Wyjaśniono istotę i definicje przedsiębiorstwa międzynarodowego, także ilość BIZ w Polsce w roku 2014. Na podstawie statystyk pokazano, że napływ BIZ do Polski ma tendencję wzrostową. Zanalizowano też wpływ BIZ na PKB w Polsce w latach 2000-2013. Zestawiono też kierunki napływu BIZ do Polski od roku 2008 do roku 2013. Podstawowa uwaga została skierowana na szanse i zagrożenia związane z obecnością przedsiębiorstw międzynarodowych $\mathrm{w}$ Polsce.

\section{Słowa}

kluczowe: bezpośrednie inwestycje zagraniczne, BIZ, przedsiębiorstwo międzynarodowe, rynekmacierzysty, rynekgoszczacy, internacjonalizacja.

\section{References}

1. Bezpośrednie inwestycje zagraniczne w Polsce w 2013 roku (2015), [in:] Departament Strategii i Analiz, Ministerstwo Gospodarki, Warszawa.

2. Bielewska A. (2006), Finanse zagraniczne MSP. Wybrane elementy, PWN Warszawa.

3. Czupiał J. (2011), Przedsiębiorstwo międzynarodowe. Skrypty UE we Wrocławiu, Wyd. UE we Wrocławiu, Wrocław.

4. Duliniec E. (2004), Marketing międzynarodowy, PWE, Warszawa.

5. Fonfara K. (2009), Istota $i$ zakres procesu internacjonalizacji firmy [in:] K. Fonfara (ed.), Zachowania przedsiębiorstwa w procesie internacjonalizacji. Podejście sieciowe, PWE Warszawa.

6. Griffin R.W. (1996), Podstawy zarządzania organizacjami, PWN, Warszawa.

7. Grabowski T. (1998). Wzorzec rynkowego zachowania przedsiębiorstwa, [in:] Otta W.J. (ed.), Droga do rynku - aspekty mikroekonomiczne, Wydawnictwo Akademii Ekonomicznej w Poznaniu, Poznań.

8. Liberska B. (2002), Globalizacja a korporacje międzynarodowe [in:] Liberska B. (ed.), Globalizacja. Mechanizmy i wyzwania, Wyd. PWE Warszawa.

9. Lichtarski J. (ed.) (2001), Podstawy nauki o przedsiębiorstwie, Wyd. 4 zmienione i rozszerzone, Wyd. AE im. Oskara Langego we Wrocławiu, Wrocław.

10. Jarczewska- Romaniuk A. (2004), Przedsiębiorstwa międzynarodowe, Oficyna Wydawnicza Branta, Warszawa.

11. Michalski E. (2012), Marketing. Podręcznik Akademicki, PWN, Warszawa. 
12. Porter M. (1990), Competitive Adventage of Nations, Free Press, New York.

13. Przedsiębiorstwo międzynarodowe, (2011), Skrypty UE we Wrocławiu, Wyd. UE we Wrocławiu, Wrocław.

14. Przytuła S. (2007), Pozyskanie menedżerów do przedsiębiorstw międzynarodowych, Wolters Kluwer Polska- Oficyna, Warszawa.

15. Rymarczyk J. (2004), Internacjonalizacja i globalizacja przedsiębiorstwa, Wyd. PWE SA, Warszawa.

16. Sadłakowski D. (2015), Analiza kosztów gospodarczych wynikających z naptywu bezpośrednich inwestycji zagranicznych, Studia i Prace Wydziału Nauk Ekonomicznych i Zarządzania No. 41, Part III, Uniwersytet Szczeciński, Szczecin.

17. Służyński S. (1997), Globalizacja rynków a przemiany w zarządzaniu przedsiębiorstwem, „Instytucja Rynku Wewnętrznego i Konsumpcji”, Warszawa.

18. Sudoł S. (2006), Przedsiębiorstwo. Podstawy nauki o przedsiębiorstwie. Zarzadzanie przedsiębiorstwem, PWE, Warszawa.

19. Zaorska A. (1998), Ku globalizacji?, Wyd. PWN, Warszawa.

20. Yip G.S. (2004), Strategia globalna, PWE Warszawa.

21. http://www.paiz.gov.pl/polska_w_liczbach/inwestycje_zagraniczne (31.01.2016 - access date).

22. https://www.funduszeeuropejskie.2007-2013.gov.pl/Strony/glowna. aspx, (01.02.2016 - access date). 